\title{
Revenue decentralization and income distribution
}

\author{
Bilin Neyapti* \\ Bilkent University, Ankara-Turkey
}

Received 11 June 2005; received in revised form 1 March 2006; accepted 24 March 2006

Available online 17 August 2006

\begin{abstract}
Due to varying local revenue collection capacities and interest group activities, revenue decentralization (RD) may lead to increased inequality. This paper provides empirical evidence, however, that, if coupled with good governance, RD could improve income distribution.

(C) 2006 Elsevier B.V. All rights reserved.
\end{abstract}

Keywords: Revenue decentralization; Fiscal decentralization; Income distribution

JEL classification: $\mathrm{H} 23 ; \mathrm{H} 71$

\section{Introduction}

This paper investigates the relationship between fiscal decentralization and income distribution. One channel through which these variables can be linked is the already existing inequalities across the regions of a country with respect to economic activity, cultural and demographic characteristics. Given such inequalities that often also imply income differentials, different profiles of local spending needs and revenue collection capacities are likely to be observed across regions. Focusing on cross-regional differentials in revenue collection capacity, one can argue that the greater the extent of revenue decentralization (RD), the worse may be income distribution. This hinges upon the argument that, since income differentials would likely to coincide with politically powerful interest groups that could better

\footnotetext{
* Tel.: +90 31229020 30; fax: +90 3122665140 .

E-mail address: neyapti@bilkent.edu.tr.
} 
manipulate the local authorities than they could the central authority, this may lead to inefficiencies in revenue collection and thus widen the income gaps both within regions and, thus, across the country.

Hence, higher RD could possibly lead to inefficient and/or unequitable revenue collection decisions due to underutilization of the revenue potential of politically powerful groups. ${ }^{1}$ Both Bradhan and Mookherjee (1998) and Blanchard and Shleifer (2000) argue that if local vested interests are powerful, in the absence of local accountability, decentralization could increase social fragmentation. RD may thus widen income gaps within localities, which would manifest in increased inequality at the country level as well. This effect, however, can be limited or eliminated by good governance that provides checks and balances in fiscal activities. Moreover, since local governments are more familiar with local revenue sources than central governments, decentralization may lead to more efficient and/or equitable revenue collection under good governance.

Few recent studies have analyzed the macroeconomic effects of fiscal decentralization (FD), with a particular focus on RD. Jin and Zou (2002), for example, have demonstrated that RD has a limiting impact on the size of the aggregate government. Both King and Ma (2001) and Neyapti (2004) show that $\mathrm{RD}$ has a negative impact on inflation, where the latter shows that this effect is reinforced by both central bank independence and local accountability. Neyapti (2005) also shows that good governance, structural and institutional factors enhance the negative effect of RD on deficits. Hence, regardless of the type of the macroeconomic variable whose association with FD is investigated, almost all theoretical and empirical studies on fiscal decentralization emphasize the effect of institutional environment on the effectiveness of FD.

Against this background, the main hypothesis of this paper is formulated as follows: in case of good governance, RD may help to improve income distribution. In other words, we expect a non-negative ASSOCIATION between RD and the GINI coefficient unless there is good governance. This paper provides an empirical test of this hypothesis using a panel study that has a time dimension of three at most, standing for the past three decades. The analysis provides strong support in favor of our hypothesis, indicating that $\mathrm{RD}$ does indeed make income distribution more equal in case of good governance.

The paper is organized as follows. Section 2 outlines the data and methodology. Section 3 presents the empirical results and Section 4 concludes.

\section{The model, data and methodology}

Suppose that each local government has an effort level $e_{i}$ for tax collection, call it tax effort. Hence, total tax collection for local government $i$ is:

$$
T_{i}=\sum_{j} e_{i j} \cdot t_{i j} \cdot L_{i j} ; i=1 \ldots . . R ; j=1 \ldots . J_{i}
$$

where $t$ is the average tax rate across all local governments and $L_{i j}$ represents the local taxable resources in region $i$, belonging to group $j$. We may assume that the tax rates are determined centrally and thus $t_{i j}=t_{j}$. To further simplify the problem without loss of generality, we may assume that all regions have

\footnotetext{
${ }^{1}$ In a similar spirit, Verardi (2005) demonstrates the positive link between the degree of proportionality in the electoral systems and income equality. Verardi conducts his analysis in a set of highly democratic countries, utilizing a different measure of income inequality (based on Luxembourg Income Study) than the one used in the current paper (Deninger and Squire, 1996). The current study uses not only highly democratic set of countries that are selected based mainly on the availability GINI coeffients.
} 
the same composition of socio-economic interest groups, although their political power may differ from region to region. We consider that different political powers of $J$ groups in each region reflect upon the tax collection effort $e_{i j}$, where $0 \leq e_{i j} \leq 1$. Then, our hypothesis is that when at least some of the $J_{i}$ groups, the number of which may differ from locality to locality, are more influential than the rest of the groups and appear to have special interests, then $T_{i}$ may differ across the regions not only in $L_{i}$, but also in $e_{i j}$. This means that while $L_{i}$ already constitutes a source of deviation in tax collection capacity across the regions, a further source of variation in tax collection is the tax effort. As we argue here, tax effort may reflect relative political influences of different socio-economic groups across the regions on the local government's ability to collect taxes. Indeed, even if $e_{i j}$ are the same across $i$ but different across the $J$ groups in each region, the argument here would still be valid.

This set up implies that different tax burdens on each group $j$ can arise even beyond the effects of $t_{j}$ and $L_{i j}$. We argue that $e_{i j}$ being at the discretion of each local government $i$ in case revenue collection is decentralized indicates greater discretion, or variability in $e_{i j}$, than a central government choice of an $e_{j}$ in case of no fiscal decentralization. It is due to the potential of such unequal treatment of various constituencies by local governments that we argue that RD may widen income disparities, and hence worsen income distribution. On the other hand, we argue that good governance amounts to both equal and full tax effort, in the sense of collecting the tax revenues pertaining to all $J$ groups in an equal fashion such that $e_{i j}=1$ for all $j$. If local governments have a better account of, and access to, local resources $\left(L_{i j}\right)$ than the central government, RD may actually lead to more equal income distribution under good governance.

To test our hypothesis, we employ the following model:

$$
\mathrm{Y}-\text { dist }=f(\mathrm{RD}, \text { control variables })
$$

where Y-dist stands for income distribution and measured by (the logarithm of) GINI coefficient (1GINI, where the larger numbers indicating worse distribution), based on Deininger and Squire (1996). ${ }^{2}$ The data are in averages over the past three decades: 1970s, 1980s and 1990s, where available. As for the control variables, we use per capita income in constant Dollar terms (Ypc) in logarithms. ${ }^{3}$ Another potential control variable is inflation since it has a redistributive role via market frictions or expectational asymmetries. We use a transformed version of inflation: $D^{4}$, to eliminate the possible estimation problems emanating from the large variations in the inflation rate across countries. To these, we add RD, and the governance variables in interaction with $\mathrm{RD}$. RD is calculated as the revenue obtained by local and state and provincial levels of the government in ratio to aggregate government revenues. Governance variables, obtained from Kaufmann et al. (2002), are: control of corruption (contcorr), rule of law (rule), political instability (polins), governmental efficiency (goveff), voice and accountability (voacc) and regulatory quality (requal). ${ }^{5}$

\footnotetext{
2 The data is also available online, at: http://www.worldbank.org (search by the title: Measuring Income Inequality Database). We only employ the "accept" category for the GINI coefficient that stands for high quality data.

3 According to Kuznets (1955), the relationhsip between income distribution and the level of income is an inverted U shape. To test this hypothesis we also performed the estimation with both Ypc and Ypc-squared terms. But the results did not change, with the additional term being found insignificant.

${ }^{4} D=$ inflation rate/ $(1+$ inflation rate $) . D$ is used to eliminate the large cross-country differences in inflation figures so as to increase efficiency of estimation.

5 The estimates for each of all the six governance variables are based on an analysis of wide-ranging data sources-comprised of both polls and surveys conducted in individual countries (see, Kaufmann et al., 2002).
} 
We consider that the random errors method is more suitable for these estimations than the fixed effects model since neither the number of countries nor the number of observations employed are sufficiently large. The data set consists of three decade averages of GINI coefficient for 37 countries. The sample can be characterized as mainly cross-sectional as the total number of observations is only one for some countries and a few for some others, adding up to 54 in total. ${ }^{6}$ The following section reports the estimation of the following models.

$$
\begin{aligned}
& \mathrm{Y}-\text { dist }=\text { constant }+\beta_{1} \mathrm{RD}+\beta_{2} D+\beta_{3} \mathrm{Ypc}+\beta_{4} \mathrm{LA} \\
& \mathrm{Y}-\text { dist }=\text { constant }+\alpha_{1} \mathrm{RD}^{*} \text { governance }+\alpha_{2} D+\alpha_{3} \mathrm{Ypc}+\alpha_{4} \mathrm{LA}
\end{aligned}
$$

where LA stands for a dummy for Latin American countries that, on average, exhibit greater income inequalities than could be explained by the control variables.

\section{Regression results}

Table 1 presents the results of the random effects estimation of both models (1 and 2). Due to high correlations between RD and its interactions with the governance variables, we report the results of the regression separately for $\mathrm{RD}$ and for the interactive variables. ${ }^{7}$

As the table indicates, neither inflation nor income levels explain the differences in income distribution across the countries. In addition, while the level of income seems to have a favorable effect on income distribution, this effect becomes insignificant once RD is used as an explanatory variable. RD has a significant negative effect on the GINI coefficient (where the logarithm is simply used to overcome the possible scale problems in estimation, while using it in levels yields very similar results) when it is interacted with the governance indicators (columns 3 to 8). RD, by itself, however does not seem to significantly affect income distribution. In addition, LA dummy is significant and indicates that, having controlled for inflation, income levels and degree of revenue decentralization, Latin America has worse income distribution than the rest of the countries in the sample.

We tried another specification that replaces either $\mathrm{RD}$ or $\mathrm{RD} *$ governance with $\mathrm{RD}$ that is in interaction with a dummy that takes the value of 1 in case there exist local elections. Those regressions returned no significant result for this additional variable, indicating that the existence of local elections, which proxies for local accountability as Neyapti (2005) argues, does not improve the results obtained above.

The results reported in Table 1, however, may leave one wondering about the part of the effect of $\mathrm{RD}^{*}$ governance that is attributable to the RD alone. Indeed, once both $\mathrm{RD}$ and the governance terms are used separately in the same regression, one observes that only the governance variables are significant with a negative sign, where RD has an insignificant coefficient. ${ }^{8}$ This appears to indicate that it is governance, and not RD that has an effect in reducing the GINI coefficient.

\footnotetext{
${ }^{6}$ We report the country and decade observations used in the empirical analysis in the Appendix.

${ }^{7}$ We observe that if we estimate the effects of RD and RD* governance together, RD gets a positive and significant coefficient and the other gets a negative significant one.

${ }^{8}$ On the other hand, using both RD and RD*governance together leads to a positive-turned coefficient of RD itself, which is one of the indications of multicollinearity (see, Greene, 1993, for example).
} 
Table 1

Estimation of models (1) and (2) with random effects

\begin{tabular}{|c|c|c|c|c|c|c|c|c|}
\hline \multirow[t]{3}{*}{ Explanatory Variables: } & \multirow[t]{3}{*}{1} & \multirow[t]{3}{*}{2} & 3 & 4 & 5 & 6 & 7 & 8 \\
\hline & & & \multicolumn{6}{|l|}{ Governance } \\
\hline & & & Voacc & Polins & Goveff & Requal & Rule & Contcorr \\
\hline RD(revenue decent.) & & $\begin{array}{c}-0.44 \\
(-1.48)\end{array}$ & & & & & & \\
\hline RD*governance & & & $\begin{array}{l}-0.75 \\
(-2.27)^{* *}\end{array}$ & $\begin{array}{l}-0.87 \\
(-2.41)^{* *}\end{array}$ & $\begin{array}{c}-0.93 \\
(-2.66)^{* *}\end{array}$ & $\begin{array}{l}-0.74 \\
(-2.20)^{* *}\end{array}$ & $\begin{array}{l}-0.86 \\
(-2.61)^{* *}\end{array}$ & $\begin{array}{c}-0.89 \\
(-2.62)^{* *}\end{array}$ \\
\hline$D=\inf /(1+\mathrm{inf})$ & $\begin{array}{c}-0.03 \\
(-0.36)\end{array}$ & $\begin{array}{c}0.07 \\
(0.44)\end{array}$ & $\begin{array}{c}0.06 \\
(0.35)\end{array}$ & $\begin{array}{c}0.05 \\
(0.30)\end{array}$ & $\begin{array}{c}0.04 \\
(0.28)\end{array}$ & $\begin{array}{c}0.06 \\
(0.37)\end{array}$ & $\begin{array}{c}0.04 \\
(0.28)\end{array}$ & $\begin{array}{c}0.04 \\
(0.25)\end{array}$ \\
\hline Income per capita & $\begin{array}{l}-0.03 \\
(-1.95)^{*}\end{array}$ & $\begin{array}{l}0.00 \\
(0.01)\end{array}$ & $\begin{array}{c}0.01 \\
(0.41)\end{array}$ & $\begin{array}{l}0.02 \\
(0.58)\end{array}$ & $\begin{array}{c}0.02 \\
(0.68)\end{array}$ & $\begin{array}{l}0.01 \\
(0.36)\end{array}$ & $\begin{array}{l}0.02 \\
(0.68)\end{array}$ & $\begin{array}{c}0.02 \\
(0.73)\end{array}$ \\
\hline Latin America dummy & $\begin{array}{l}0.27 \\
(4.14)^{* * *}\end{array}$ & $\begin{array}{l}0.32 \\
(3.09)^{* * *}\end{array}$ & $\begin{array}{l}0.29 \\
(3.03)^{* * *}\end{array}$ & $\begin{array}{l}0.29 \\
(3.08)^{* * * *}\end{array}$ & $\begin{array}{l}0.27 \\
(2.84)^{* * *}\end{array}$ & $\begin{array}{l}0.31 \\
(3.25)^{* * *}\end{array}$ & $\begin{array}{l}0.26 \\
(2.69)^{* * *}\end{array}$ & $\begin{array}{l}0.27 \\
(2.74)^{* * *}\end{array}$ \\
\hline Constant & $\begin{array}{c}3.84 \\
(31.86)^{* * *}\end{array}$ & $\begin{array}{l}53.64 \\
(16.81)^{* * *}\end{array}$ & $\begin{array}{c}3.58 \\
(16.86)^{* * *}\end{array}$ & $\begin{array}{c}3.55 \\
(16.63) * * *\end{array}$ & $\begin{array}{c}3.53 \\
(16.78)^{* * *}\end{array}$ & $\begin{array}{c}7.64 \\
(16.81)^{* * *}\end{array}$ & $\begin{array}{c}8.64 \\
(16.81)^{* * *}\end{array}$ & $\begin{array}{c}9.64 \\
(16.81)^{* * *}\end{array}$ \\
\hline R-bar squared & 0.92 & 0.98 & 0.98 & 0.98 & 0.98 & 0.98 & 0.98 & 0.98 \\
\hline \# of observations & 97 & 54 & 54 & 54 & 54 & 54 & 54 & 54 \\
\hline
\end{tabular}

Dependent variable: Income distribution (logarithm of GINI coefficient).

Notes: Figures in parentheses are the $t$-ratios. $D=[$ inflation rate $/(1+$ inflation rate $)]$. RD $=$ Ratio of local and state government revenues in total revenues of the government.

* Reject null at $10 \%$ significance level.

** Reject null at 5\% significance level.

*** Reject null at $1 \%$ significance level.

It is also possible to argue that the relationship between governance and $\mathrm{RD}^{9}$ is causing some estimation problems. In order to capture the effect of RD on GINI, one may therefore need to concentrate on the part of RD - that is not correlated with governance. Hence, in what follows, we apply a method to disentangle the effect of governance from RD*governance observed in columns 3 to 8 of Table 1 . To do this, we first regress RD on each of the governance terms and use the residuals emerging from that regression in interaction with governance, along with the governance terms. This method can be regarded as a robustness test of the interpretation provided for columns 3 to 8 above. $^{10}$

The modified model therefore is:

$$
\mathrm{Y}-\text { dist }=\text { constant }+\gamma_{1} \text { RDresid }^{*} \text { governance }+\gamma_{2} \text { governance }+\gamma_{3} D+\gamma_{4} \mathrm{Ypc}+\gamma_{5} \mathrm{LA}
$$

where RDresid is obtained from the regression of $\mathrm{RD}$ on each governance term, and stands for-the part of the RD term that is not explained by governance. Hence, we expect that if RD has an effect on GINI in the presence of good governance, beyond the effect of good governance itself, $\gamma_{1}$ should be negative and significant. Table 2 reports the estimation of Model (3) using the six governance terms.

\footnotetext{
${ }^{9}$ The correlation between $\mathrm{RD}$ and the various governance measures ranges from $8 \%$ to $17 \%$.

${ }^{10}$ In addition, we applied the Hausman test of endogeneity, where we used expenditure decentralization as an instrument, besides the LA dummy, D, Ypc and each of the governance variables at a time, to explain RD.Using the residuals of this first stage of estimation to estimate Y-dist yields no significant coefficients of the residual terms, supporting our method that assumes lack of endogeneity in RD.
} 
Table 2

Estimation of model (2)

\begin{tabular}{|c|c|c|c|c|c|c|}
\hline \multirow[t]{3}{*}{ Explanatory variables: } & 1 & 2 & 3 & 4 & 5 & 6 \\
\hline & \multicolumn{6}{|l|}{ Governance: } \\
\hline & Voacc & Polins & Goveff & Requal & Rule & Contcorr \\
\hline RDresid*governance & $\begin{array}{l}-1.19 \\
(-1.97)^{* *}\end{array}$ & $\begin{array}{c}-1.31 \\
(-2.04)^{* *}\end{array}$ & $\begin{array}{c}-1.56 \\
(-2.45)^{* *}\end{array}$ & $\begin{array}{l}-1.16 \\
(-1.91)^{*}\end{array}$ & $\begin{array}{c}-1.41 \\
(-2.34)^{* * *}\end{array}$ & $\begin{array}{c}-1.53 \\
(-2.46)^{* *}\end{array}$ \\
\hline Governance & $\begin{array}{l}-0.49 \\
(-3.36)^{* * *}\end{array}$ & $\begin{array}{l}-0.51 \\
(-3.04)^{* * * *}\end{array}$ & $\begin{array}{c}-0.66 \\
(-4.46) * * *\end{array}$ & $\begin{array}{l}-0.64 \\
(-3.74)^{* * *}\end{array}$ & $\begin{array}{c}-0.51 \\
(-3.65) * * *\end{array}$ & $\begin{array}{c}-0.52 \\
(-3.64) * * *\end{array}$ \\
\hline$D=\inf /(1+\inf )$ & $\begin{array}{c}0.07 \\
(0.50)\end{array}$ & $\begin{array}{c}0.05 \\
(0.33)\end{array}$ & $\begin{array}{c}-0.03 \\
(-0.21)\end{array}$ & $\begin{array}{c}0.04 \\
(0.28)\end{array}$ & $\begin{array}{r}0.005 \\
(0.04)\end{array}$ & $\begin{array}{l}-0.0002 \\
(-0.00)\end{array}$ \\
\hline Income per capita & $\begin{array}{c}0.03 \\
(1.21)\end{array}$ & $\begin{array}{c}0.03 \\
(1.23)\end{array}$ & $\begin{array}{l}0.06 \\
(2.15)^{* *}\end{array}$ & $\begin{array}{c}0.04 \\
(0.28)\end{array}$ & $\begin{array}{l}0.05 \\
(1.62)\end{array}$ & $\begin{array}{l}0.05 \\
(1.67)^{*}\end{array}$ \\
\hline Latin America dummy & $\begin{array}{l}0.27 \\
(3.41)^{* * * *}\end{array}$ & $\begin{array}{l}0.27 \\
(3.25)^{* * * *}\end{array}$ & $\begin{array}{l}0.17 \\
(2.21)^{* * *}\end{array}$ & $\begin{array}{l}0.32 \\
(4.23)^{* * *}\end{array}$ & $\begin{array}{l}0.18 \\
(2.11)^{* *}\end{array}$ & $\begin{array}{c}0.21 \\
(2.60) * * *\end{array}$ \\
\hline Constant & $\begin{array}{c}3.64 \\
(19.35)^{* * * *}\end{array}$ & $\begin{array}{c}3.63 \\
(18.77)^{* * *}\end{array}$ & $\begin{array}{c}3.48 \\
(18.71)^{* * *}\end{array}$ & $\begin{array}{c}3.73 \\
(20.55)^{* * *}\end{array}$ & $\begin{array}{c}3.52 \\
(18.40)^{* * *}\end{array}$ & $\begin{array}{c}3.49 \\
(18.15)^{* * *}\end{array}$ \\
\hline R-bar squared & 0.98 & 0.98 & 0.98 & 0.98 & 0.98 & 0.98 \\
\hline \# of observations & 54 & 54 & 54 & 54 & 54 & 54 \\
\hline
\end{tabular}

Dependent variable: Income distribution (logarithm of GINI coefficient). (Random effects model)

Notes: Figures in parentheses are the $t$-ratios. $D=[$ inflation rate $/(1+$ inflation rate $)]$. RD $=$ Ratio of local and state government revenues in total revenues of the government.

* Reject null at 10\% significance level.

** Reject null at 5\% significance level.

*** Reject null at $1 \%$ significance level.

The results reported in Table 2 strongly confirm the prediction that in the presence of good governance, revenue decentralization helps to make income distribution more equal and the magnitude of this effect appears to be greater than the direct effect of good governance on GINI. ${ }^{11}$ While the remainder of the control variables yield virtually the same results as in Table 1, in columns 3 and 6 we observe positive effects of income per capita, which is possibly due to its high correlation with governance (more than $80 \%$ with each of the 6 governance terms).

Though we choose not to report here again for the possible biases due to multicollinearity, the regressions in Table 2 are also repeated with RDresid's added as separate terms in all the six columns. Those results also generally confirm the results reported in Table 2, except that RDresid turns out to be insignificant in the first and the forth columns only. ${ }^{12}$ This provides a further robustness check for the general result that, even though RDresid is negative and significant (at lower levels of significance) itself for four out of the six regressions corresponding to different governance measures, its interaction with governance is robustly significant and negative, besides the significantly negative governance terms.

\footnotetext{
${ }^{11}$ If the first stage, where residuals from the regression of RD on governance are obtained, is performed with ordinary least squares rather than random effects technique, then the findings are partially supportive. In the case OLS technique is performed for the first stage, the estimation of model (3) yields significant negative coefficients for RD* governance in cases of voacc; polins and rule; and insignificant one in the rest of the cases. Table 2 above reports the results of random effects model used in the first stage as well.

12 Those results are available upon request from the author.
} 


\section{Conclusions}

The panel investigation in this paper indicates that revenue decentralization may have a favorable impact on income distribution if accompanied with good governance. The impacts of inflation or income level on income distribution, on the other hand, are not found robustly significant. The policy implication that emerges is that revenue decentralization is an advisable policy reform-provided that good governance exists. This finding is also consistent with the existing studies on the effects of fiscal decentralization.

\section{Acknowledgments}

I would like to thank Tarýk Akýn for his excellent research assistance in the data collection process. I also owe thanks to Ferhat Emil and an anonymous referee.

\section{Appendix A. The list of countries and decades used in the analysis}

\begin{tabular}{|c|c|}
\hline Countries & Decade \\
\hline Australia & $80 s$ \\
\hline Australia & $90 \mathrm{~s}$ \\
\hline Belgium & $80 s$ \\
\hline Belgium & $90 \mathrm{~s}$ \\
\hline Bolivia & $80 s$ \\
\hline Bolivia & $90 \mathrm{~s}$ \\
\hline Brazil & $80 s$ \\
\hline Canada & $80 s$ \\
\hline Canada & $90 \mathrm{~s}$ \\
\hline Chile & $80 s$ \\
\hline Chile & $90 \mathrm{~s}$ \\
\hline Costa Rica & $80 s$ \\
\hline Denmark & $80 s$ \\
\hline Denmark & $90 \mathrm{~s}$ \\
\hline Dominican Republic & $80 s$ \\
\hline Dominican Republic & $90 \mathrm{~s}$ \\
\hline Finland & $80 s$ \\
\hline Finland & $90 \mathrm{~s}$ \\
\hline Greece & $80 s$ \\
\hline Guatemala & $80 s$ \\
\hline India & $80 s$ \\
\hline India & $90 \mathrm{~s}$ \\
\hline Indonesia & $80 s$ \\
\hline Indonesia & $90 \mathrm{~s}$ \\
\hline Iran, Islamic ep. & $80 s$ \\
\hline Ireland & $80 \mathrm{~s}$ \\
\hline Italy & $80 s$ \\
\hline Italy & $90 \mathrm{~s}$ \\
\hline
\end{tabular}


Appendix A (continued)

\begin{tabular}{|c|c|}
\hline Countries & Decade \\
\hline Luxembourg & $80 \mathrm{~s}$ \\
\hline Mauritius & $80 \mathrm{~s}$ \\
\hline Mexico & $80 \mathrm{~s}$ \\
\hline Mexico & $90 \mathrm{~s}$ \\
\hline Netherlands & $80 \mathrm{~s}$ \\
\hline Netherlands & $90 \mathrm{~s}$ \\
\hline Nicaragua & $90 \mathrm{~s}$ \\
\hline Norway & $80 \mathrm{~s}$ \\
\hline Norway & $90 \mathrm{~s}$ \\
\hline Panama & $80 \mathrm{~s}$ \\
\hline Peru & $90 \mathrm{~s}$ \\
\hline Portugal & $80 \mathrm{~s}$ \\
\hline South Africa & $90 \mathrm{~s}$ \\
\hline Spain & $80 \mathrm{~s}$ \\
\hline Sri Lanka & $80 \mathrm{~s}$ \\
\hline Sweden & $80 \mathrm{~s}$ \\
\hline Sweden & $90 \mathrm{~s}$ \\
\hline Thailand & $80 \mathrm{~s}$ \\
\hline Thailand & $90 \mathrm{~s}$ \\
\hline Trinidad and Tobago & $80 \mathrm{~s}$ \\
\hline Tunisia & $80 \mathrm{~s}$ \\
\hline United Kingdom & $80 \mathrm{~s}$ \\
\hline United Kingdom & $90 \mathrm{~s}$ \\
\hline United States & $80 \mathrm{~s}$ \\
\hline United States & $90 \mathrm{~s}$ \\
\hline Zimbabwe & $90 \mathrm{~s}$ \\
\hline
\end{tabular}

\section{References}

Blanchard, O., Shleifer, A., 2000. Federalism with and without Political Centralization: China versus Russia. Working Paper Series (U.S.), vol. 7616. National Bureau of Economic Research, pp. 1-14. March.

Bradhan, P., Mookherjee, D., 1998. Expenditure Decentralization and the Delivery of Public Services in Developing Countries. CIDER Working Paper, vol. C98-104. Center for International and Development Economics Research, Berkeley, California.

Deininger, K.W., Squire, L., 1996. A new data set measuring income inequality. World Bank Economic Review (10), 565-591. Greene, W.H., 1993. Econometric Analysis. MacMillen Press.

Jin, J., Zou, H., 2002. How does fiscal decentralization affect aggregate, national, and subnational government size? Journal of Urban Economics 52 (2), 270-293.

Kaufmann, D., A. Kraay and P. Zoido-Lobaton, "Governance Matters II: Updated Indicators for 2000/01”. World Bank Policy Research Department Working Paper, 2002.

King, D., Ma, Y., 2001. Fiscal decentralization, central bank independence and inflation. Economic Letters 72, 95-98.

Kuznets, S., 1955. Economic growth and income inequality. American Economic Review 45 (1), 1-28.

Neyapti, B., 2004. Fiscal decentralization, central bank independence and inflation. Economics Letters 82, 227-230.

Neyapti, B., 2005. Fiscal Decentralization and Deficits: International Evidence, mimeograph, Bilkent University.

Verardi, V., 2005. Electoral systems and income inequality. Economics Letters 86, 7-12. 